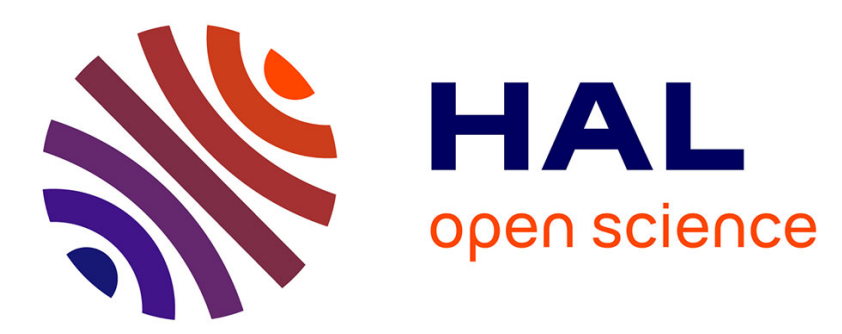

\title{
Magma, a model to help animal manure management at the farm level
}

\author{
Francois Guerrin
}

\section{To cite this version:}

Francois Guerrin. Magma, a model to help animal manure management at the farm level. International Conference on Modelling and Control in Agricultural, Horticulture and Post-Harvest Processing, Jul 2000, Wageningen, Netherlands. 327 p. hal-02765786

\section{HAL Id: hal-02765786 \\ https://hal.inrae.fr/hal-02765786}

Submitted on 4 Jun 2020

HAL is a multi-disciplinary open access archive for the deposit and dissemination of scientific research documents, whether they are published or not. The documents may come from teaching and research institutions in France or abroad, or from public or private research centers.
L'archive ouverte pluridisciplinaire HAL, est destinée au dépôt et à la diffusion de documents scientifiques de niveau recherche, publiés ou non, émanant des établissements d'enseignement et de recherche français ou étrangers, des laboratoires publics ou privés. 


\section{MODELLING AND CONTROL IN AGRICULTURE, HORTICULTURE AND POST-HARVEST PROCESSING (Agricontrol 2000)}

A Proceedings volume from the $1^{\text {st }}$ IFAC International Conference, Wageningen, The Netherlands, $10-12$ July 2000

Edited by

G. van STRATEN, K.J. KEESMAN

Systems Control Group, Department of Agrotechnology and Food Sciences, Wageningen University, Wageningen, The Netherlands,

and

\section{J. BONTSEMA}

Department of Advanced Systems, Institute of Agricultural and Environmental Engineering, IMAG, Wageningen The Netherlands

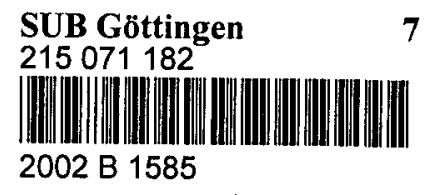

Published for the

INTERNATIONAL FEDERATION OF AUTOMATIC CONTROL

by

\section{PERGAMON}

An Imprint of Elsevier Science 


\section{CONTENTS}

\section{AGRICULTURAL PRODUCTION TECHNOLOGY AND ROBOTICS}

Tasks for Agricultural Engineering Research: New Challenges - New Trends?

A. MUNACK

Statistical Aspects of Sampling Sprays

H.J. HOLTERMAN

Modelling of Mechanical Loads on Potato Tubers

K. GOTTSCHALK, J. WINKELMANN

An Automatic Tractor Guidance

P. BALSARI, M. TAMAGNONE

Identification of a Mathematical Model for a Combine Header Simulator Device

G.T. LOPES, P.S.G. MAGALHĀES, E.G.O. NÓBREGA

Optimization Tool for Qualitative Performance Analysis of Agro-Industrial Machinery

G. RIVA, E. FOPPA PEDRETTI, G. TOSCANO, G. TUMMARELLO

Motion Planning for a Cucumber Picking Robot

E.J. VAN HENTEN, G. VAN DIJK, M.C. KUYPERS, B.A.J. VAN TUIJL, L.G. VAN WILLIGENBURG

Development of an Automated and Modular System for Slurry Tanks

F. MAZZETTO, S. LANDONIO, M. SALVI

\section{ANIMAL PRODUCTION}

A Dairy Cattle Loose Housing Simulation Model, to Evaluate the Performance of an Automatic Milking System

P. LIBERATI

Automatic Receding Horizon Optimal Control of the Natural Ventilation Process in Cattle Barns

M. TIMMERMAN, L.G. VAN WILLIGENBURG, A. VAN 'T OOSTER

Integrated Control Strategy for Processes in Fattening Pig Systems

I.H.G. SATTER, E. VANTHOOR, K.J. KEESMAN

MAGMA: A Model to Help Animal Manure Management at the Farm Level

F. GUERRIN

\section{PROTECTED CULTIVATION}

Scheduling and Control of Crop Production for Advanced Life Support

D.H. FLEISHER, K.C. TING

Root Shoot Partitioning and Nitrate Concentration in Lettuce

R. LINKER, I. SEGINER

Acceptable Nitrate Concentration of Greenhouse Lettuce: An Optimal Control Policy for Temperature,

Plant Spacing, and Nitrate Supply

I. IOSLOVICH, I. SEGINER 


\section{GREENHOUSE CLIMATE AND NUTRIENT CONTROL}

Simulation of Humidity Control and Greenhouse Temperature Tracking in a Growth Chamber Using a Passive Air Conditioning Unit

R. TAWEGOUM, R. TEIXEIRA, G. CHASSÉRIAUX

Application of Radial Basis Function Neural Networks to a Greenhouse Inside Air Temperature Model

P.M. FERREIRA, E.A. FARIA, A.E.B. RUANO

Proportional-Integral-Plus (PIP) Control of Agricultural Buildings

J. TAYLOR, L. PRICE, P. LEIGH, P. YOUNG, D. BERCKMANS, K. JANSSENS, E. VRANKEN, R. GEVERS

Three Time-Scale Digital Optimal Receding Horizon Control of the Climate in a Greenhouse with a Heat

Storage Tank

L.G. VAN WILLIGENBURG, E.J. VAN HENTEN, W.Th.M. VAN MEURS

Constrained Predictive Control of a Greenhouse

S. PIÑÓN, M. PEÑA, C. SCHUGURENSKY, B. KUCHEN

Control of Crop Growth and Nutrient Supply by the Combined Use of Crop Models and Plant Sensors

L.F.M. MARCELIS, R. VAN DEN BOOGAARD, E. MEINEN

Analysis of Solute Movement in Inert Substrates

Th.H. GIELING, G. VAN STRATEN, B.W. VEEN

Modeling $\mathrm{pH}$ and Electrical Conductivity in Hydroponics using Artificial Neural Networks

K.P. FERENTINOS, L.D. ALBRIGHT, N.R. SCOTT

\section{POST-HARVEST PROCESSING AND STORAGE}

Solving Dual Optimization Problems in Identification and Performance of Fed-Batch Bioreactors

J.F.M. VAN IMPE, K.J.E. VERSYCK

On-Line Controller Tuning for Unstable Processes with Application to a Biological Reactor

K.G. ARVANITIS, N.A. SIGRIMIS, G.D. PASGIANOS, G. KALOGEROPOULOS

Applying Grey Theory to Identify the Dried Temperatures of Roselles

H.-H. CHEN, T.-C. HUANG, Y.-M. SU, P.-J. TSAI

A Study on Drying Characteristics of Kahramanmaras Red Pepper 
An Algorithm for the Prediction of Freezing Times and Heat Loads Adequate to Use for the Control of Food Freezing Equipment

V.O. SALVADORI, R.H. MASCHERONI

CFD Simulations of Chicory Root Palloxes for Cool Storage

M.L. HOANG, P. VERBOVEN, B.M. NICOLAÏ

Aspects of Control Structure Selection in Post-Harvest Processes

G.J.C. VERDIJCK, L.J.S. LUKASSE, J.J.M. SILLEKENS

Identification and Optimal Control of Fruit Responses During Storage, as Affected by Heat Treatment

T. MORIMOTO, K. TU, T. AONO, Y. HASHIMOTO

Using Modeling Techniques to Test the Feasibility of Segregating Non-GMO Soybeans at Commercial Elevators

R. BERRUTO, D.E. MAIER

Shelf-Life of Some Vegetables in Novel MA and Active Packages

T. LYIJYNEN, T. LUOMA, R. AHVENAINEN

Modelling Mealiness Dynamics in Apples as Related to Texture Parameters

P. BARREIRO, B.E. VERLINDEN, V. DE SMEDT, B. NICOLAÏ

Modelling the Milk Powder Equilibrium Moisture Content under Storing Conditions

J. STENCL, J. GOTTHARDOVA

\section{IMAGING AND SENSORS}

Biomechatronics for Agro-Industrial Applications

H. MURASE

Water Uptake of Seeds Observed by Dynamic Neutron Radiography

F. KŐRÖSI, M. BALASKÓ, E. SVÁB

An Experimental Technique to Measure Gas Transport Properties of Fruit

W. SCHOTSMANS, B.E. VERLINDEN, J. LAMMERTYN, B.M. NICOLAII

Low-Cost, Real-Time Inspection of Oranges Using Machine Vision

E. MOLTÓ, N. ALEIXOS, J. BLASCO, F. NAVARRÓN

Non-Destructive and Destructive Firmness Measurements on Apples and Peaches

S. LANDAHL, N. DE BELIE, J. DE BAERDEMAEKER, A. PEIRS, B. NICOLAÏ

Multivariate Imaging for Automated Process Control in the Agro Industry

W.H.A.M. VAN DEN BROEK, J.C. NOORDAM, A. PAULI

K. HATOU, T. TAKEUCHI, Y. HASHIMOTO

River Water Quality Modeling via Verhaegen and Dewilde's Method

C.P. BOTTURA, G. BARRETO, A.F. TORRICO CÁCERES 